\title{
The Origin of the Child Healthcare in the East Coast of Sumatra, 1900s-1940s*
}

\section{DEVI ITAWAN}

Magister Sejarah, Universitas Gadjah Mada

Email: itawandevi@gmail.com

\begin{abstract}
This article aims to explore the issue of children's healthcare in the context of colonial expansion on the East Coast of Sumatra. At the early of the 20th century, the birth rate, children, and maternal healthcare have become important issues in discussing health conditions in plantations in East Sumatra. It was a significant shift concerning the realm of East Sumatra plantation health and medical research due to since in the pioneering time, plantation's medical institutions merely focused on the health of adult male coolies. The phenomenon of high rate of infant mortality in the early 20th century has become a new health problem in the East Coast of Sumatra Plantation. The plantation companies convincing to take further care of the children's health as it will give a direct effect on plantation hygiene and population growth of the region. In the East Coast of Sumatra, children's healthcare discourse was a proxy of the colonial capitalism interest, hygiene problems, and needs of population growth.
\end{abstract}

Keywords: children healthcare; East Coast of Sumatra; medical research; plantation; population problem

Kata kunci: kesehatan anak; masalah kependudukan; perkebunan; Pesisir Timur Sumatera; riset kedokteran

*) Presented in join conference of The Asian Society of the History of Medicine ( $9^{\text {th }}$ meeting) and HOMSEA (History of Medicine in Southeast Asia) on June 2018 in Jakarta.

DOI

doi.org10.22146/lembaran-sejarah.59377
Article | Received

History 5-1-2020
Accepted

15-4-2020
Published 30-4-2020 


\section{Introduction}

The colonial economic expansion of the Outer Islands attained great success in the region of the East Coast of Sumatra. Hundreds of plantations were operating with an occupational area of more than 1 million hectares in the early 20th century (Encyclopedia Bereau, 1918: 128). According to Pelzer, the success was driven by favorable climates and soil, sparse population, the availability of abundant land, and the support from the local ruler and colonial government that allowed the entrepreneur to obtain land concessions easily (Pelzer, 1985: 90). The only major challenge for the development of the plantation industry was the availability of the laborers (Lindblad, in: Clemen dan Lindblad (ed.), 1989: 2-3). The natives, the Bataks and Malays, were reluctant for regular work in the plantation since they prefer to undertake small-holding cultivation in their land (Broesma, 1919: 32). The scarce of labor supply urged the planter pioneers to import a huge number of coolies from overseas; Chinese coolies from China and the Malay Peninsula, and later Javanese coolies from the Java (Pelzer, 1985: 51-64).

The sparse population of the East Coast of Sumatra resulted in abundant land for concession holdings, but on the other hand, it was a major challenge for the rest of the evolving plantation industry. Moving laborers from overseas was a huge financial burden for plantation companies, particularly since many laborers often fled due to the heavy workload on the estates. Hence, the company implemented strict rules and discipline to bind their laborers. To enforce discipline, bind the worker and prevent coolie to flee, the plantation enterprises in East Coast Sumatra apply the Peonale Sanctie. This labor legislation allowed the plantations full legal control over their coolies, included to punished them (Breman, 1997: 35-48).

Nevertheless, greater financial risk occurred when the laborers, which was brought in expensively from outside the region, died in great number from many diseases. The primeval forests were harsh environments for the planters and coolies. Here was where the forests were cut down, roads and drains dug, swamps were reclaimed, the tropical sun was fierce, the conditions were detrimental to newcomers. The work in the fields covered felling woods and rattan which often lacerated the foot causing wounds that progressively became deadly unless vigorous treatment was applied. Annual immigrations from China, Java, Borneo, Bawean and British India often brought with them diseases from outside the region. Cholera and beriberi were the major infectious diseases found in early pioneering period. Opium abuse among coolies deteriorated their health further (Cremer, 22/1889: 21-261).

To prevent financial losses due to sick and dead coolies, the plantations initiated the development of a health service. Initially, the health service on the plantations was limited to curative measures. During early period, modest hospitals were set up and placed under the supervision of a hospital assistants 
or pharmacists hired in the Straits Settlement, who often had received his training at the Madras College. In 1871, the first European doctors were brought in, and in the same year, the first plantation hospital was founded by the Deli Maatschappij (Cremer, 22/1889: 21-261). Since then, every plantation was required to have a hospital. The requirement to treat sick coolies was legally provisioned in the Peonale Sanctie (Volker, 1928: 24).

Curative measure was considered not vigorous enough to combat infectious diseases. Dr. Schaffner supported by the Deli Planters Vereeniging (DPV), paved the way for the development of tropical medical research by establishing a pathology laboratory in Medan (Gedenkboek DPV, 1929: 213215). With the pathology laboratory, plantation health services was not limited to curative measures but included efforts for disease control in the plantations of the East Coast.

Initially, the plantation population was mostly males and health services were exclusively addressed to them. Nevertheless, the demographic composition shifted when the plantation companies started the colonization program since the early twentieth century. The program allowed Javanese coolies to bring along his wife and children and set up permanent settlements (Broesma, 1922: 160-182). The presence of women and children subsequently stimulated the shift in hygiene and medical research to maternal and child health studies, notably reproductive health, women fertility and birth rates. The research into child health were conducted after increased awareness of the high infant mortality rates in many plantations, especially after the 1920s (De Sumatera Post, 28 December 1939).

The shift of hygiene and medical research toward children and women in the plantation was peculiar and paradoxical, as the plantation health research was constituted for the maintenance of the health of the coolies, which were generally adult males. Besides, the strict marriage arrangements previously imposed on the East Sumatra plantations imply that the plantation community does not support the presence of children. Why then came the interest to do research and conduct child health care program in the plantation? Did the research and child health care program in plantation merely urge by purely scientific work for combatting the high infant mortality epidemic in the plantation or behind the scientific work bear the greater colonial interest in the plantation region of the East Coast of Sumatra?

The discourse on child health care in this discussion is placed on the part of the colonial population issue. The object of the studies is focused on the population in the plantation area, which mainly focused on the Javanese, as they become dominant in numbers since the early twentieth century and directly impacted of colonization program. I employed a social historical approach to health. Boomgard had criticized the approach regarding the study of the colonial health of Indonesia which tends to apply a custodial approach, 
instead of studying the social history of health (Boomgard, 1993: 77-93). The emphasis of the discussion is on the interest of researchers, planters, and the colonial government on the health of children, as well as the increased interest in the health of children in the plantation of East Sumatra. I presume that the population increase in eastern Sumatra by as much as five times in the 1930 census in comparison to the pre-plantation period as partially the result of the establishment of children's health care.

\section{Women and Children in the Plantations}

The felling forests and preparation of land was not something that women and especially children were expected to do. Therefore, in the early period, the presence of women and children was very rare (Stoler, 1983: 51). Coolie women began to be imported in 1879 by Deli Maatschappij along with the first Javanese coolies to the East Coast of Sumatra. Until the early twentieth century, their number were very low compared to men. According to Breman, in 1905 the number of Javanese women coolies was only 6209 souls, whereas the number of Javanese coolie men was 33.961 souls. The number of women was only $6 \%$ of the men in 1905 (Breman, 1997: 67). Meanwhile, Stoler (1983: $50)$ and Baay (2017: 154) estimated that in the early twentieth-century women only made up 10-12\% from the total labor force in the east coast.

In the early twentieth century, the ratio among white women and men in Deli was 1 to 3, mostly composed of wives and daughters of administrators. Aside from the scarcity of white women, the plantation company in the East Coast also enacted strict marriage rules among the white assistant. Until 1919, the plantation companies established "a marriage ban" for their white assistants. The strict marriage rules regulated by the company only allowed the assistant to marry European women after a minimum of six years of work in the estates. To obtain marriage permission, they are also required to have a certain amount of sufficient savings (Baay, 2017: 157). Women, particularly white women, were considered unsuitable and unable to survive in the harsh environment. Besides, bringing women were more expensive, especially if they want to build a family (Baay, 2017: 148-149). Therefore, instead of married the company encouraged the assistant to take Javanese concubines.

The unbalanced gender ratios in the plantation led to many problems concerning the biological needs among the assistants and the coolies. The lack of women stimulated sodomy and pederasty. Many young men were sexually exploited. This phenomenon was a serious issue for the plantation companies since sexual perversion sometimes lead to extraordinary scandals (Baay, 2017: 151). Ann Stoler pointed out that the initial purpose for the recruitment of Javanese women was to fulfil the biological needs of adminstrators and coolies as prostitutes and concubines (Stoler, 1983: 50). They were systematically 
forced into concubinage or prostitution as a result of their insufficient wage to meet daily basic dietary needs. For Javanese women coolies, becoming prostitutes and concubines were the only available opportunities to earn additional income. Meanwhile, for the men, prostitutes and concubines were the only way to meet their biological needs (Stoler, 1983: 50-53; Baay, 2017: 152). Although considered as moral degeneracy in the colonial community, prostitution and concubinage became a common practice to substitute conjugal relations up to the 1920s (Stoler, 1983: 55).

The presence of women and children in the plantations became the main focus for medical and hygienic programs and research. The main health problems for women was related to reproductive health. Syphilis was common as a result of concubinage and prostitution. There are no reliable data on deaths due to syphilis, but Van Kol's statement, as cited by Ann Stoler, stated that most Javanese women and male coolie died in plantation hospitals because of syphilis (Stoler, 1983: 52-53).

Concubinage and prostitution also impacted female fertility rates. Straub revealed that women contract coolies were less fertile than free workers. This was most likely due to the practice of abortion and sterilization (Straub, 1928:7). The child was not something to be expected from sexual activity in the estates on the East Coast of Sumatra. Mandelon Lulofs in her novel Rubber implied the common practice of abortion amongst Javanese concubines. Women were burdened with contraception issues. Meanwhile, pregnancy and birth were solely the responsibility of the woman. Pregnancy often forced a mistress to be returned to the estates' ward, and raising children was troublesome in such an environment. These circumstances led to the neglect and exploitation of children in the plantation. Stoler disclosed that

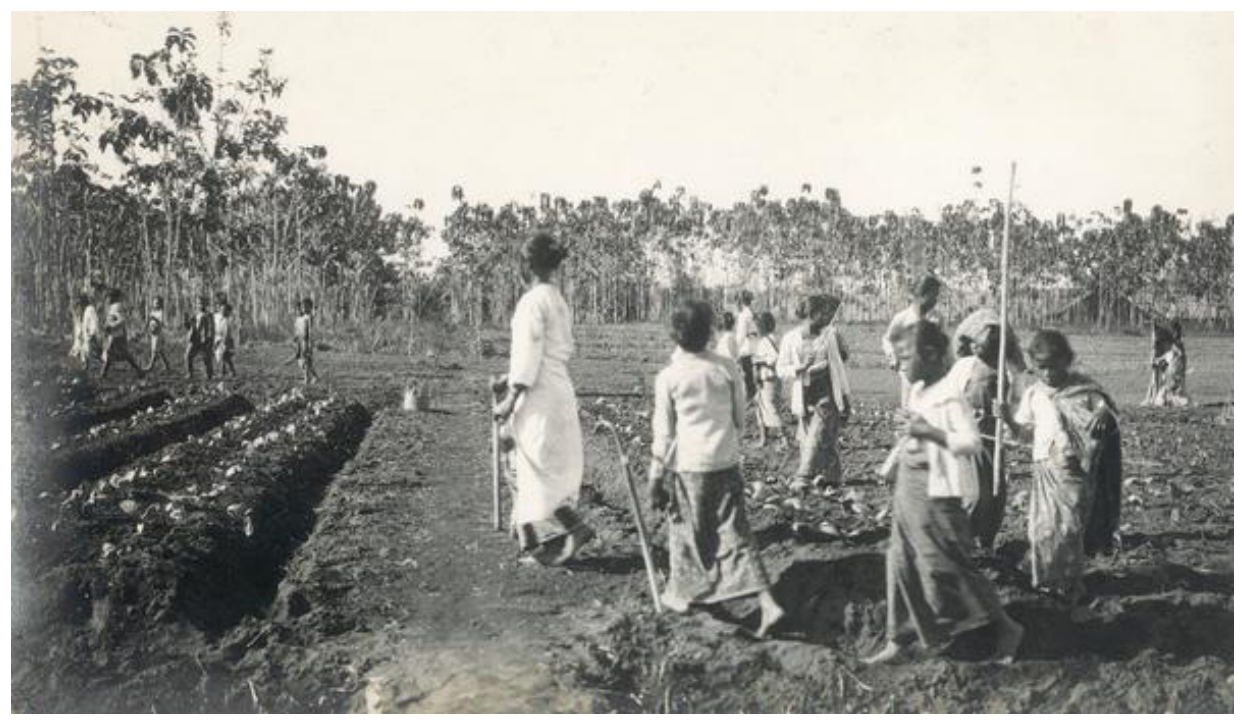

Figure 1. Children at work on a tobacco plantation in Deli on the East coast of Sumatra. Source: KITLV Digital Collection,( http://hdl.handle.net/1887.1/item:909666) 
prostitution and concubinage resulted in poor morale for Javanese mothers, which resulted in the common practice of child neglect and trafficking by indentured coolies. Many left their children from illegitimate relations in Sumatra when they returned to Java (Stoler, 1983: 53).

Women and children were thus exploited both physically and sexually. In the context of labor, women and children were additional workforce in the plantation. They were also employed in the fields. They assisted in drying, fermenting, binding, sorting, and cumulating the tobacco in warehouses. Nevertheless, the number of women and children coolie was much greater in the plantations of palm oil, tea, and fiber compared to tobacco plantations (Westerman, 1901: 21-22). Women and children sometimes did night work in rubber plantations. The involvement of women and children in production activities was affirmed the poor conditions for laborers in the East coast. This drew the attention of many groups, including the League of Nations which had outlawed the employment of women and children in plantations. The Deli Planters Association (Deli Planters Vereening or DPV) objected to the League's decision for the ban led which they say lead to a decline in production and profit earnings, especially in rubber, tea, sisal, and oil palm plantations. The labor of women and child were discussed in newspapers in the Netherlands and Netherlands Indies (De Telegraaf, 03 June 1924; Bataviaasch Nieuwsblad, 27 June 1925).

\section{Children Health Care}

In the 1920s, high rates of infant mortality highlighted the health care issues in plantations in the East Coast. This was the result of the findings from labor inspections (Batavia Nieuwsblad, 11-10-1920). Many health practitioners of the East Coast were interested to study this phenomenon. Dr. Baerman from Serdang Doctor Fonds, in a meeting in Medan 1924 were among the health practitioners, colonial government, and plantation companies, that responded to the problem of high infant mortality in plantations. He had found that the height of infant mortality occurred in the first four months of a child's life and is attributable to insufficient rice, improper treatment and insufficient care from mothers because of their plantation work. Many died as a result of malaria and lung inflammation (Nieuwe Rotterdamsche Courant, 17 October 1924; Nieuwe Rotterdamsche Courant, 10 August 1926.).

Infant mortality was a catastrophic health problem that had to be overcome. It drew public attention ${ }^{1}$ and drove actions from scientists, government, and companies. The studies were pioneered by scientists from the Serdang Doctor Fonds; dr. Baerman, Dr. Smits and dr. Straub. Straub had

1) Many of newspapers in Netherland Indies and the Netherlands discussing the high rate of infant mortality in the East Coast Sumatera, i.e. Batavia Newsblad, 18-11-1920, De Sumatra Post, 13-01-1928, Nieuwe Rotterdamsche Courant 17-10-1924. 
written a dissertation on the high infant mortality rate in the East Coast. To combat infant mortality, a second meeting was held on May 15, 1926. In the meeting Dr. Smits showed that in 1925 the birth rate was 29.1 per thousand in the 24 plantations he researched. The mortality rate of infants in 1926 was 23.2 per 100 births. Smits suggested measures against infant mortality: strengthening the civil status of women, regular inspections, malaria research, encouragement to hospitalization, epidemic control. He also recommended that all women who have given birth to visit the hospital at regular intervals, in order to recognize early weak and sick children, and to convince mothers of the usefulness of hospital visits (Batavia Nieuwsblad, 13 September 1927; Nieuwe Rotterdamsche Courant, 10 August 1926).

The meetings produced resolutions to combat infant mortality. It included curative, preventive, and administrative actions:

1. Establish a system of marriage, birth, and infant mortality registration,

2. Regular control of infants and children, particularly concerning malaria handling as well as inflammatory pneumonia that infects infants and children,

3. Provide special treatment to mothers and infants, which included the release of work for women who are in the early stages of labor and after delivery, routine inspections of mothers and infants,

4. If the disease was marked by decreasing body weight, it must immediately get treatment in hospital with his mother,

5. Provision of hygienic and supervised baby nurseries,

6. In the long term, plantation companies will train local nurses to be employed in the hospital's children room, besides producing certified midwives (Straub, 1928: 12-13).

Dr. Straub became a leading researcher on infant mortality particularly after his doctoral research was published by the Colonial Institute in Amsterdam (Tropisch Hygiene).

Tabel 1. Infant mortality rate in several estates in the East Coast of Sumatra.

\begin{tabular}{cccc}
\hline East Coast of Sumatra & Birth & Death & Percent \\
\hline H.A.P.M (Hollandsch Amerikaansche Plantage Mij) 1924-1926 & 1857 & 687 & $37 \%$ \\
Deli Mij (kebun tembakau) 1925-1926 & 4145 & 1153 & $28 \%$ \\
Serdang Doctor Fonds 1925-1926 & 1012 & 241 & $24 \%$ \\
Deli Mij (kebun karet) 1924-1926 & 227 & 59 & $26 \%$ \\
Senembah Mij (kebun tembakau) 1926 & 497 & 94 & $19 \%$ \\
\hline
\end{tabular}

Source: Dr. M. Straub, 1922, p. 33

In his dissertation, dr. Straub encompassed a medical-hygiene and colonial approach. On the medical-hygiene context, he contributed 
substantially to the collection of statistical data on infant mortality. In addition to blood tests, the analysis of the health conditions of newborns were determined to cause of infant death in early childbirth. He revealed that most deaths occurred due to disruption of blood flow caused by the pattern of nutritional intake in infants. Besides scientific work, dr. Straub also supported the objectives of the plantation company. In the introduction, dr. Straub insisted that children's health care have a direct impact on the plantation. $\mathrm{He}$ regarded the health of women and children as part of the epidemiological system of the plantation. Indeed, the child is an important reservoir of the malaria epidemic. Straub said that combating malaria would not succeed if it excluded the children. While prevention of hookworm infection could not succeed if it did not take account of women in the plantations. His opinion regarding child health problems and infant mortality were that it was part of the economic and labor issues in East Sumatra's plantations (Straub: 1928,47).

\section{Children Healthcare, Colonization Program, and Population Problem}

In the preface of dr. Straub's dissertation, he explicitly illustrated why colonial governments, plantation companies, and health practitioners were interested in promoting child health care. It pointed to the linkage between the sustainability of the plantation business, the colonization program, and hygiene (Straub, 1928: 3-20).

The colonial government has a great interest in regulating the population in their colonies, including in the East Coast of Sumatra. In the East Coast, population arrangement was closely linked to the interest of the plantation industry. From the outset, the plantation company has imported a huge number of coolies from overseas which led to significant population growth (Pelzer, 1985: 83-87). Since the early twentieth century, plantation companies and the colonial government desired to run a multi-purpose colonization program. This program was also known as the free immigration program, which boosted the number of Javanese coolies and his family. They were to be the reserve workforce and to be peasant to help with the food production. This stimulated the emergence of new permanent settlements in the vicinity of plantations and changed the demographic composition of the population of the East coast, with significantly more numerous women and children (Broesma, 1922: 160-182; Breman, 1997: 67-68).

The shift of interest in plantation companies to women and children was part of the colonization program that was conducted in reaction to criticisms of indentured labor of the Poenale Sanctie. This policy was very different to the previous policies which systematically limited the presence of women and children through the banning of marriage. Criticisms of the 
Table 2. Growth of the plantation population (Javanese) in the East Coast of Sumatra between 1920 and 1927

\begin{tabular}{ccccc}
\hline & Total Population & Children & Woman Free Worker & Number of births \\
\hline 1920 & 150.669 & 49.263 & 7433 & 7836 \\
1921 & 133.031 & 51.672 & 9.186 & 8351 \\
1922 & 113.634 & 51.804 & 10.202 & 9190 \\
1923 & 107.680 & 53.067 & 9719 & 8428 \\
1925 & 122.909 & 60.228 & 10.851 & 9052 \\
1926 & 141.749 & 65.130 & 11.421 & 9553 \\
\hline
\end{tabular}

Source: Straub, 1928, p. 6

Peonale Sanctie from domestic and international community has forced the government and plantation companies to amend the coolie ordinance. The 1911 amendment resulted in the term of "free worker" or free coolie. It refers to the group of ex-contract workers who were still working on the plantations. They were living outside the plantations' accommodations and not fully bound to the plantations. Free workers brought a major shift in the labor order in East Sumatra (Breman, 1997: 42-48; De Sumatra Post, 22 July 1922).

The gradual shift in labor order also impacted health services regulation within the estates. Previously, the Peonale Sanctie forced the coolie to undergo medical treatment. Instead, free workers cannot be forced to undergo medical treatment as. The amendments to the Peonale Sanctie were disputed among the doctors in the plantations. The Ponale Sanctie indeed embraced universal health care for the coolie and the maintenance of hygiene in the plantation. Dr. Baerman contended that the improvement in medical hygiene and the successful reduction of coolie death were from infectious disease were the result of the Peonale Sanctie. The amendments were regarded as drawbacks to the hygiene and health condition (Nieuw Rotterdamsche Courant, 18-06-1929; B.M Driel, 1939/LXXI: 803-811).

The free worker scheme resulted in a new relationship between plantation and the coolies. The Ponale Sanctie forced a strong and binding relationship between the coolies and the plantations (De Sumatra Post, 2207-1922). In order to maintain that bond, the government and plantation companies integrated free immigration, coolie requirement, and the colonization program. The government brought families and set up villages for coolies around the plantation that bind their workers with the plantation. The free immigration program encouraged coolies to come to the plantation voluntarily along with their families. Plantation companies no longer house the coolies in narrow pondoks. Instead, the colonization program provided a plot of land around the plantation to built-up settlement and grow rice. The Javanese family which included the adult man, woman, and the child would be 
working in the plantation, but area also allowed to cultivate their plot of land. Meanwhile, the children became an asset for the plantation. The children were expected to be the successor of his family to labor in the plantations. They inherited the knowledge of planting while the company provided education for coolie children. Thus, a stronger bond between coolies and plantations were created (De Sumatra Post, 28 December 1939; De Tijd, 20 October 1940).

The plantations originally regarded the Javanese family who lived in the vicinity of the plantations as the property or reverse workforce for the plantation. The large number of coolies and coolie families in East Sumatra benefited the plantations because it simplifies and further saves the cost of the recruitment of laborers. Moreover, it was also a new instrument to create a new labor order to gradually replaced the Ponale Sanctie. Therefore, the context of child health promotion in East Sumatra, the rate of childbirth, infant mortality, and female fertility are important elements. The child health programs were expected to produce surplus birth providing a stream of worker through the process of reproduction. (Straub, 1928: 8).

To achieve that goal, the function of women as reproductive agents was also given special attention. Fertile female coolies can help to sustain the economic sustainability of plantations. Dr. Straub revealed that free women workers were more fertile than plantation contract laborers. Although the mortality rate is high, the birth rate remains high, thanks the free female laborers. To further promote maternal and child health, the colonial government and plantation companies organized training for indigenous midwives. Indigenous midwives were expected to be agents in combating infant mortality within plantation populations. Besides, the plantation companies also give sexual reproduction health knowledge to the girls through the education curriculum on plantations. The programs of humanizing the coolies in this plantation are applied to plantations such as in the Senembah Maatschappij (Straub, 1928: 8; Senembah Maatschappij, 1939: 75-78).

At a meeting in Amsterdam in 1939 that discussed the future of plantations in the Indies, the success of the colonial government, health practitioners, and plantation companies in combating infant mortality and building colonies in East Sumatra plantations received appreciation. It also reflects the hope of the colonial elite for a more civilized future of plantations in the Dutch East Indies. In the meeting, dr. Heinemann of Senembah Maatschappij presented a film titled youth and colonization in the economy at Deli. One of the highlights of the meeting was the rising surplus of baby births that increased to 18.5 per mile, were at that time there were more than 10,000 children on the plantation. This achievement became a hope for the future of plantations in the Indies more sustainable and civilized (De Sumatra Post, 28 December 1939).

In the 1930 census, the population of East Sumatra reached five 
times from the period before the expansion. The 1930 census reflected the success of the colonial government and plantation companies in boosted the composition of the population of East Coast Sumatra. In his visit in 1924, John Anderson estimated that the population of East Coast Sumatra was only about 35.000. The 1930 census showed that the population reached 1.693.200, with the Javanese amounting to 589.836 or about $40 \%$ of the total population. Although it is quite difficult to measure that the increased population on the East Coast as a result of child health programs, the colonization program brought major changes to the population composition. It became a colonial legacy that can still be seen from present-day East Coast Sumatra (Anderson, 1926; Thee Kian Wie, 1987: 41).

\section{Conclusion}

Before the 20th century, most plantation population were men as a result of an efficient and strict work system through contract labor. In the early 20th century this policy gradually shifted to a system of free workers. This shift in the work system became the foundation for a labor order which had a major influence on the social and demographic structure of plantations in East Sumatra. In this case, health institutions and researches become one of the main instrument in realizing this novel labor order.

The birth rate was not part of the interest in developing medical research in East Sumatra plantations before the shift in the regulation of contract coolies in the early twentieth century. In line with the growing criticism of the Peonale Sanctie, the change in the labor scheme on East Sumatra plantations with a casual worker system was initiated. To achieve that goal, the execution of the colonization program was substantial. The families in the novel labor regulation scheme were institutions that are tied to plantation companies through land granting in the plantation environment.

Child health discourse on plantations in East Sumatra is not merely driven by pure scientific interest, but it is also driven by the interests of the colonial economic sustainability. Besides, behind child health programs and colonization of plantations, there is profound colonial control over marriage, reproduction, fertility, maternal health, and children, which is profound for the first time in East Sumatra. In the context of the population problem, the health of women and children was the elementary agent. It can be termed that fertilize women were fertilizing the plantation companies and colonialism in East Coast Sumatra. Women and children became the subject of scientific hygiene and economic matter which projected the face of humanization and prosperity of the new era of colonialism on the East Coast of Sumatra. 


\section{References}

Books

Anderson, John (1826). Mission to the East Coast of Sumatra, in MDCCXXIII, under the Direction of the Goverment of Prince of Wales Island: Icluding Historical and Descriptive Sketches of the Country, and Account of Commerce, Population, and the Manners and Costums of the Inhabitans, and a Visit to the Batta Canibal States in the Interior. Blackwood: London.

Baay, Reggie (2017). Nyai dan Pergundikan di Hindia Belanda. Depok: Komunitas Bambu.

Breman, Jan (1997). Menjinakan Sang Kuli: Politik Kolonial, Tuan Kebun, Kuli di Sumatera Timur pada Awal Abad ke-20. Jakarta: PT pusataka Utama Grafiti.

Broesma, R. (1922). Oostkust van Sumatra: De Ontwikkeling van Deli. Batavia: Javasche Boekhandel \& Drukkerij.

Cremer, J.T. (1889.). 'Deli Schetsen: Geneeskundig Verpleging', dalam Eigen Haard $22: 602-607$.

Encyclopedisch Bureau Oostkust van Sumatera (1918). De Buitenzettingen Oostkust van Sumatera. Deel II. Aflevering 3. Eerste Stuk. Semarang \& Surabaya: 's-Gravenhage.

Gedenkboek D.P.V. (1929). Gedenkboek uitgegeven ter gelegenheid van het vifjtigjraig bestaan van Deli Planters Vereeniging. Batavia: Gedrukt Bij G. Kolff..

Pelzer, Karl (1985). Toean Keboen dan Petani: Politik Kolonial dan Perjuangan Agraria. Jakarta: Sinar Harapan.

Senembah Maatschappij (1939). Senembah Maatschappij 1889-1939. Compiled by C.W. Jansesn dan H.J. Bool.

Stoler, Ann L. (1985). Capitalism and Confrontation in Sumatra's Plantation Belt, 18701979. The University of Michigan Press.

Straub, M (1928). Kinderstrefte ter Ootskust van Sumatra. Amsterdam: Koninklijke Vereeniging Koniaal Instituut.

Thee Kian Wie (1977). Plantation Agriculture and Export Growth, An Economic Hitsory of East Sumatera 1863-1942. LEKNAS-LIPI: LP3ES.

Volker, T. (1928). Van Oerbosch tot Cultuurgebied: Een Schets van de Beteekenis van de Tabak, de Andere Cultures en de Industrie ter Oostkust van Sumatera. Medan : Deli Planters Vereeniging.

Westerman, William (1901). De Tabakscultuur op Sumatera's Oostkust, Amsterdam: J.H. De Bussy.

\section{Journal Articles}

Boomgaard, Peter (1993). 'Develpoment of Colonial Health Care in Java: An Exploratory Introduction'. Bijdragen tot de Taal-, Land- en Volkenkunde, Deel 149, 1ste Afl., pp. 77-93.

Van Driel, B.M. (1931). 'Tets over Zorg Gezondheidstoestand de ondernemingsarbied in de toekomst' Geneeskundig Tijdschrijft Deel LXXI. p. 803-811.

\section{Article in Book}

Lindblad, J.T. (1989). 'De Opkomst van de Buitengewesten', in Lindblad, J.T. and A.H.P. Clemen. Het Belang van Buitengwesten: Economische expansie en koloniale staatsvorming in de Buitengewesten van Nederlands-Indie 1870 - 1942. Amsterdam:NEHA, p.1-37. 


\section{Newspapers}

Bataviaasch Niewsblad, 11 October 1920

Bataviaasch Nieuwsblad, 27 June 1925

Bataviaasch Niewsblad, 13 September 1927

De Sumatra Post, 22 July 1922

De Sumatra Post, 28 December 1939

De Telegraaf, 03 June 1924

De Tijd, 20 October 1940

Nieuwe Rotterdamsche Courant, 17 October 1924

Nieuwe Rotterdamsche Courant, 10 August 1926

Nieuwe Rotterdamsche Courant, 10 August 1926

Nieuwe Rotterdamsche Courant, 18 June 1929 